技術報告

$$
\begin{gathered}
\text { カーボンナノチューブ繊維構造体を用いた } \\
\text { 分析試料固定 } \\
\text { 湯峯 卓哉*, 前野 洋平 } \\
\text { 日東電工株式会社 研究開発本部 } \\
\bar{T} 567-8680 \text { 大阪府茨木市下穂積1-1-2 } \\
\text { "takuya_yumine@gg.nitto.co.jp }
\end{gathered}
$$

（2015 年 4 月 1 日受理; 2015 年 5 月 9 日掲載決定）

近年，分析試料は微細化・表面修飾による機能性向上に伴い，表面形態および成分分布の分析 が望まれている。われわれは，カーボンナノチューブ（CNT）繊維構造体からなる固定部材を開 発し，チャージアップや，固定部材由来のコンタミを抑制することにより，最表面の形態観察お よび成分の分析が出来ることを見出した.

\title{
Carbon Nanotube-microstructure as Novel Material to Fix Specimen for SEM Surface Observation or Surface Analysis
}

\author{
Takuya Yumine* and Youhei Maeno \\ Nitto Denko Corporation, Corporate Research and Development Div. \\ 1-1-2, Shimohozumi, Ibaraki, Osaka 567-8680, Japan \\ "takuya_yumine@gg.nitto.co.jp
}

(Received: April 1, 2015; Accepted: May 9, 2015)

\begin{abstract}
In recent years, the function of materials has been improved by refinement and the surface modification, therefore an analysis of the surface morphology and the ingredient distribution is required. We have developed a fixing material made of carbon nanotube (CNT) microstructure inspired by gecko adhesive system, which inhibits contamination and charging. We found that observation of morphology of the outermost surface and an ingredient analysis became more accurate using the CNT microstructure.
\end{abstract}

1. はじめに

最表面の形態および詳細成分分布を分析する事は 製品の機能発現メカニズムを明らかにするため重要 である．現行手法では絶縁物最表面を形態観察する 際には絶縁物のチャージアップを抑制するために導 電物質によるコーティングを行う必要があり，最表 面のありのままを分析することが困難となっていた.
加えて，微小試料の成分分析を行う際には，固定部 材として用いられる導電テープ，導電ペーストによ る污染により，正確な表面情報を得ることが困難で あった。 また，ミクロンオーダーの粒子では固定部 材へ試料が沈む問題もある。日東電工(株)では，有 機物を含まない CNT 維構造体からなる固定部材 $\left(\right.$ Nitto $\left.\mathrm{Gecko}^{\circledR}\right)$ を開発し[1]，分析用途への検討を 


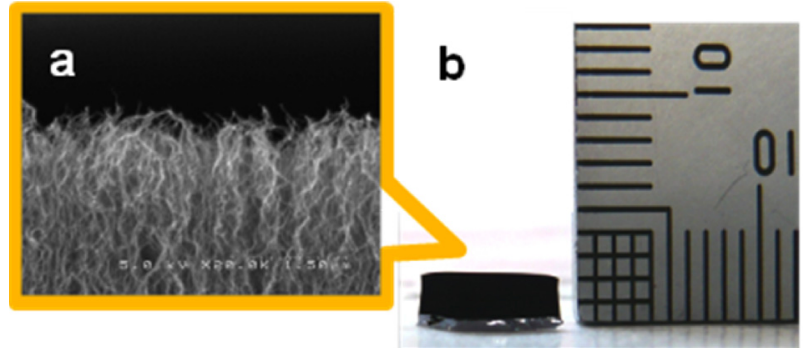

Fig. 1. (a) SEM image and (b) optical photograph of Nitto Gecko $^{\circledR}$.

行っている. Nitto Gecko ${ }^{\circledR} の$ 写真を Fig. 1 に示寸. 汎 用の粘着剤や接着剤は流動性のある有機物が濡れる 事で被着体と粘着，接着剂の距離を近づけ特性を発 現する。一方, Nitto Gecko ${ }^{\circledR}$ では CNT の微細構造が 試料に近づく事で接着特性が発現される。導電性が 高く有機物を含まない CNT を使う事で試料の チャージアップや，固定部材由来のコンタミを抑制 し, 無蒸着で微小試料表面を形態観察, 表面分析で きることを見出した.
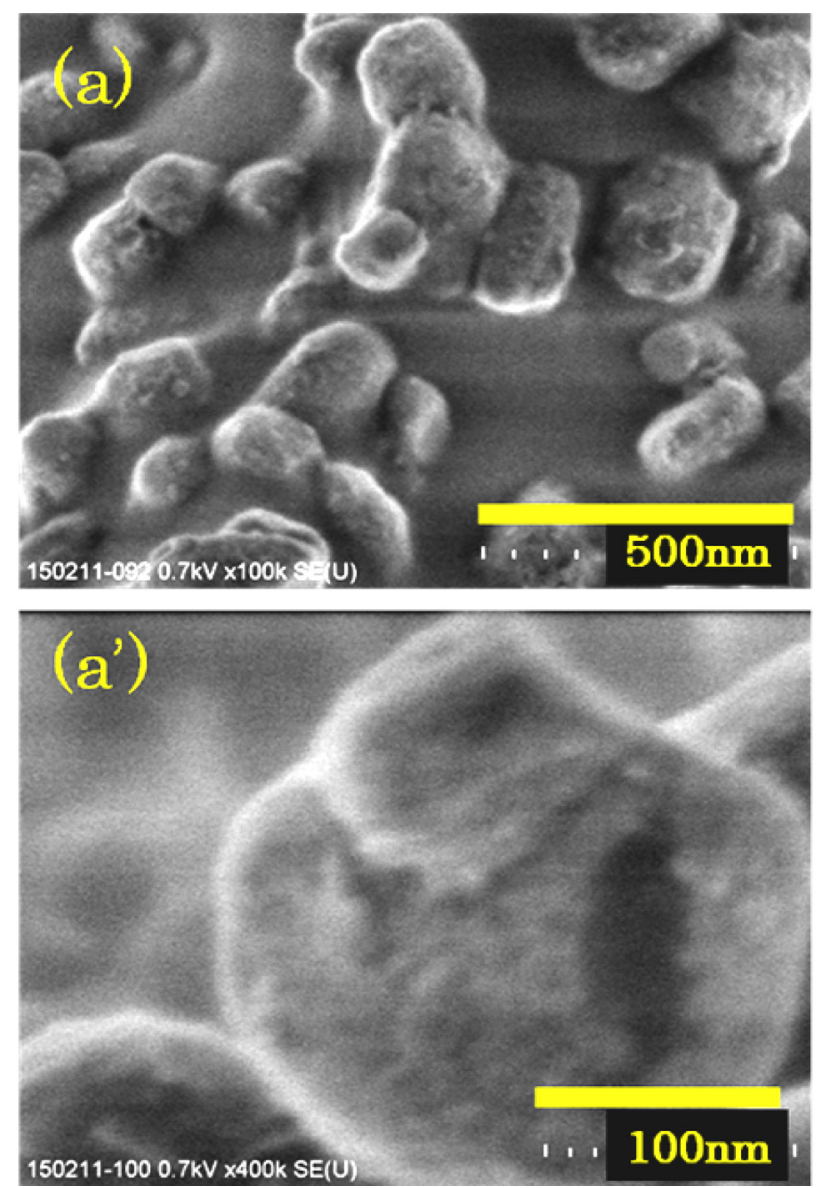

\subsection{FE-SEM 観察}

Fig. 2 は電界放出形走査電子顕微鏡（FE-SEM： Field Emission-Scanning Electron Microscope）にて絶 縁性の酸化チタンの微粒子を汎用の導電性両面テー プおよび Nitto Gecko ${ }^{\circledR} に$ 固定し形態観察を行った結 果である．観察装置は日立八イテクノロジーズ社製 SU8020を用いている.汎用のテープでは試料がテー プに沈むだけでなく，粒子表面にテープ成分由来の 污染と考えられる輝度の低いコントラストが観察さ れる他，導電性が低いためにチャージアップやドリ フトにより微粒子表面の微細凹凸を観察できない. 一方，Nitto Gecko ${ }^{\circledR}$ を用いることにより，試料污染や ドリフトが抑制され，試料表面の微細なポーラス形 状が明瞭に観察することが出来ている.
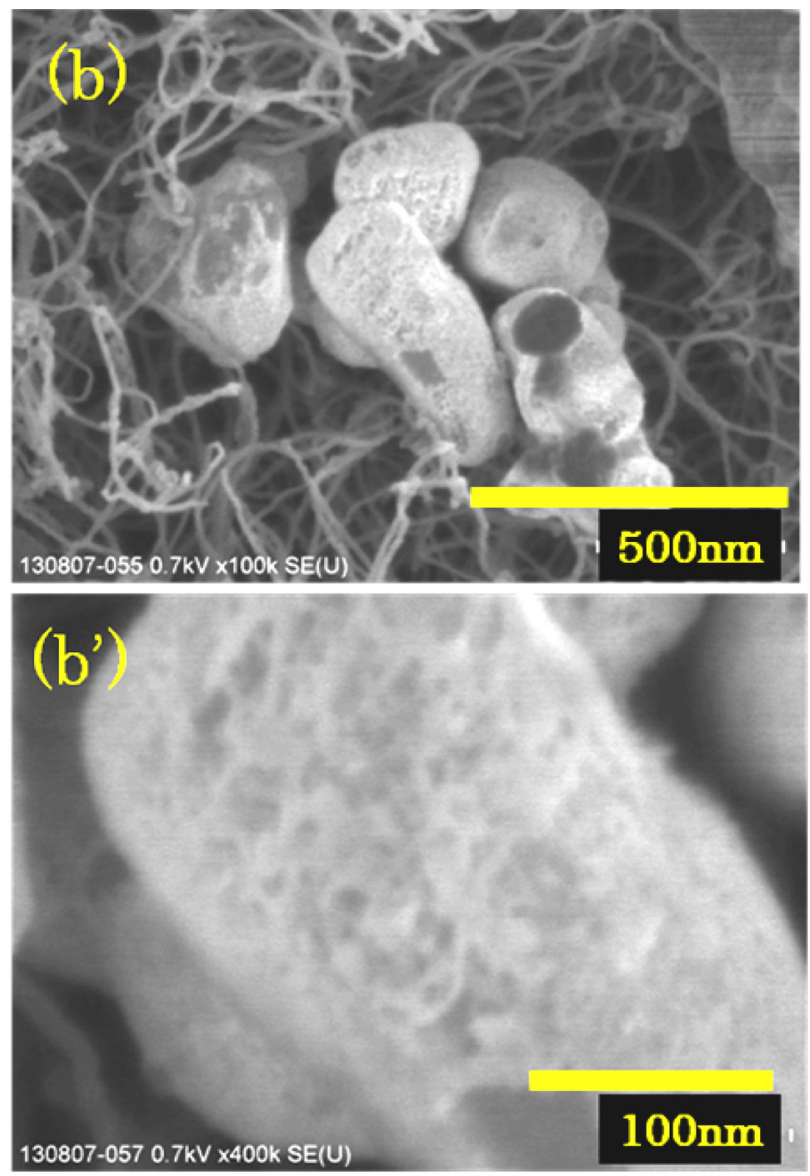

Fig. 2. SEM images of $\mathrm{TiO}_{2}$ nano-particles, (a)(a') fixed by organic double-sided tape, and (b)(b') fixed by Nitto Gecko ${ }^{\circledR}$. 


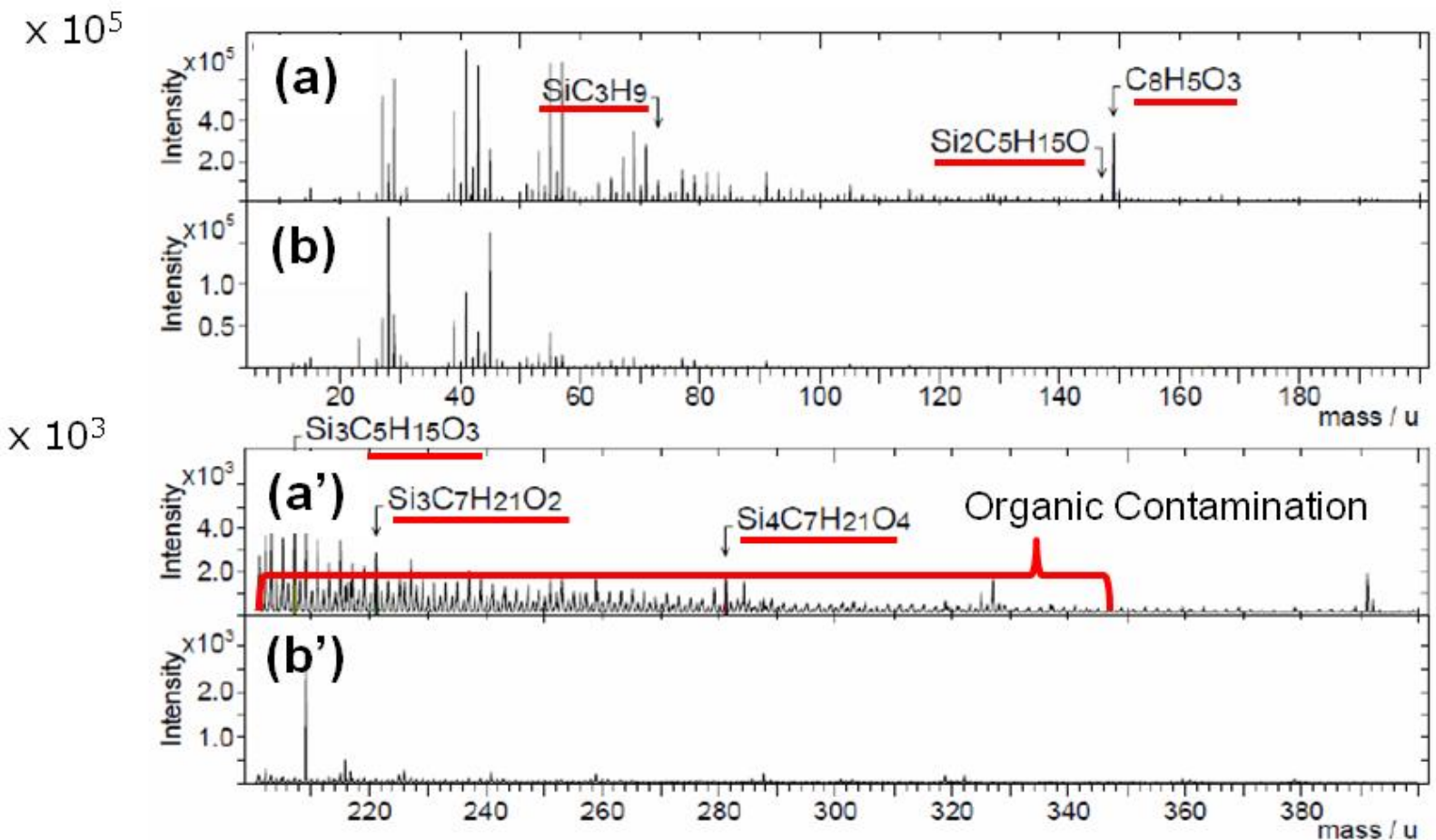

Fig. 3. TOF-SIMS spectra of zeolite particles, (a)(a') fixed by organic double-sided tape, and (b)(b') fixed by Nitto Gecko ${ }^{\circledR}$.

\subsection{TOF-SIMS 分析}

サブ〜数ナノメートルの分析深さの飛行時間型二 次イオン質量分析装置（TOF-SIMS : Time-of-Flight Secondary Ion Mass Spectrometer) でミクロンサ イズの試料を導電性両面テープ表面に粒子を分散固 定すると，固定部材の成分が試料表面を污染し，表 面成分を正確に分析できない事や，固定部材表面の 污染由来の信号が試料からより強く検出される事で, データーを見誤る事がある．特に，固定部材に由来 する成分が分析目的成分と類似であった場合, 評価 が困難である。一方，Nitto Gecko ${ }^{\circledR}$ を用いた固定をす ることで，污染成分を含まない評価が出来る. Fig. 3 は粒径 $100 \mu \mathrm{m}$ 程度のゼオライト粒子を真空系の分 析装置で試料を固定する際によく用いられる導電性 両面テープおよび Nitto Gecko®表面に分散した後の 試料表面を, Fig. 4 は粒径数 $10 \mu \mathrm{m}$ の Acrylonitrile Butadiene Styrene (ABS) 標準ポリマーの粒子を金 (Au) およびNitto Gecko ${ }^{\circledR}$ 表面に振り掛けて分散さ せた試料を TOF-SIMS で分析した結果である。分析
装置は ION-TOF 社製 TOF.SIMS 5 を用いている. 導 電性両面テープ，Au そして Nitto Gecko ${ }^{\circledR}$ で固定した 粒子の表面を TOF-SIMS で分析し比較すると, 導電 性両面テープで固定したゼオライト粒子表面からは, テープ由来の成分が検出されている。また， $\mathrm{Au}$ で ABS 標準ポリマーを固定しイオンイメージを取得 すると $\mathrm{Au}$ 表面からも試料と類似の成分が検出され ることで試料/固定部材の界面が不明瞭なものとな る. Totalイオン像では試料表面より $\mathrm{Au}$ 表面からの 方が試料よりシグナルが強く検出され，コントラス トが逆転したようなイメージとなってしまう。これ らの結果は, $\mathrm{Au}$ 表面に実験環境に漂う有機成分が自 然に付着する事で発生していると判断される。しか し，Nitto Gecko ${ }^{\circledR}$ で固定した試料の表面は，それらに 比べて大幅に固定部材表面の污染が少ないため，試 料表面のありのままの姿を評価でき，固定部材に由 来する試料污染の影響の無いイメージを取得出来る 事が明らかとなった。 

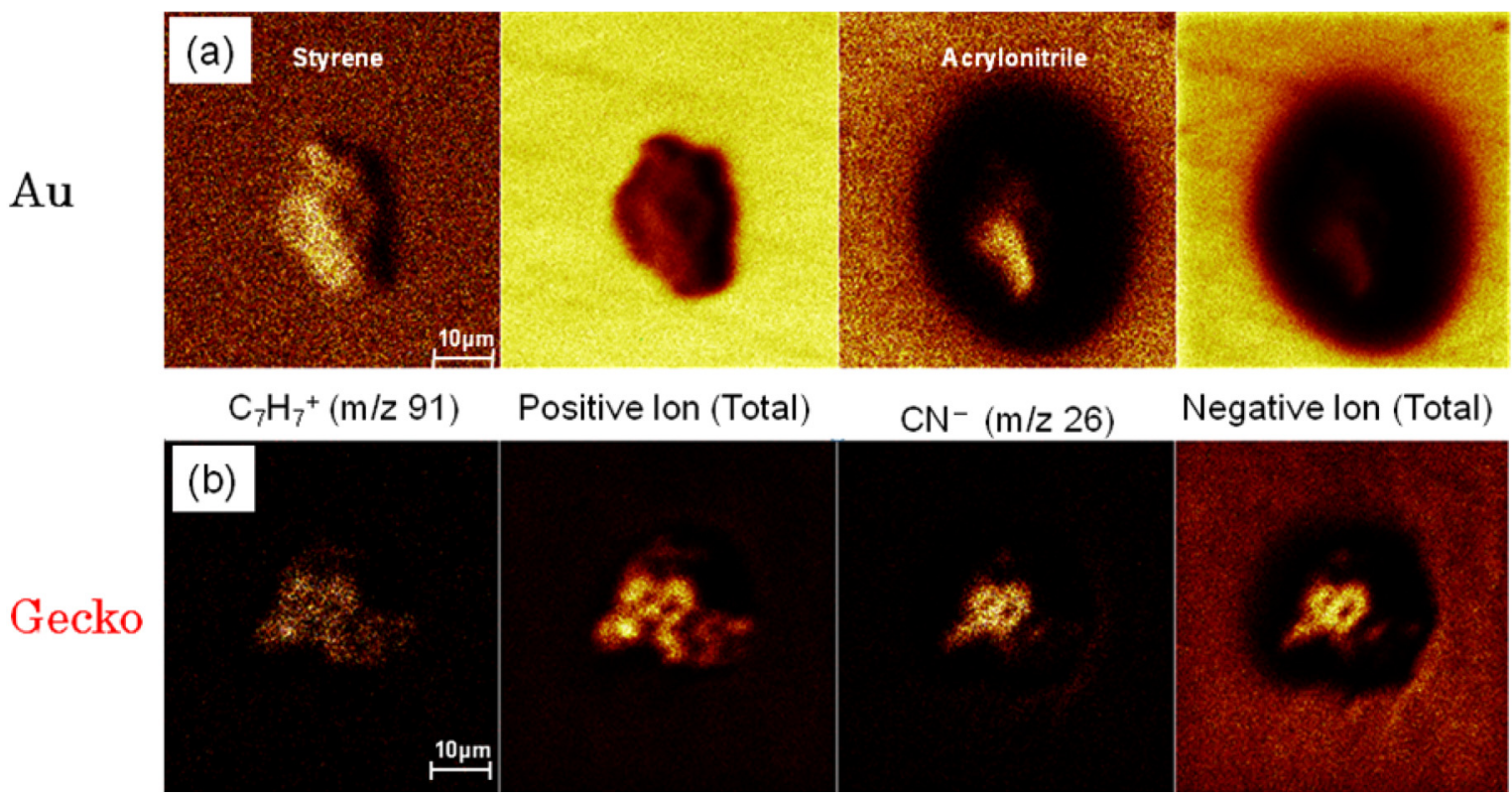

Fig. 4. TOF-SIMS images of ABS resin, (a) fixed by Au sheet, and (b) fixed by Nitto Gecko ${ }^{\circledR}$.

\subsection{FE-AES 分析}

ナノメーターレベルでの深さ方向分析を行なう電 界放射型オージェ電子分光装置（FE-AES：Field emission type Auger Electron Spectrometer) でミクロン サイズの粒子の深さ方向分析をする場合, エッチン グエリアが試料より十分に広く，固定部材由来の物 の試料への再付着量がエッチング量を上回る. その ため本来，炭素が存在しない試料内部からも炭素が 検出され, 試料内部に存在する炭素の分布を確認す

る事は困難である. Nitto Gecko ${ }^{\circledR} て ゙$ 固定をすることで 再付着による炭素が検出されない深さ方向分析が可 能である. Fig. 5 は粒径 $5 \mu \mathrm{m}$ 程度の酸化銅の粒子を FE-AES でアルゴンエッチングによる深さ方向の分 析をした結果である. 分析装置はアルバックファイ 社製 SAM680 を用いている.汎用の導電性両面テー プを用いると，試料表面にテープ由来と考えられる 炭素が検出されるだけでなく，試料内部からもエッ
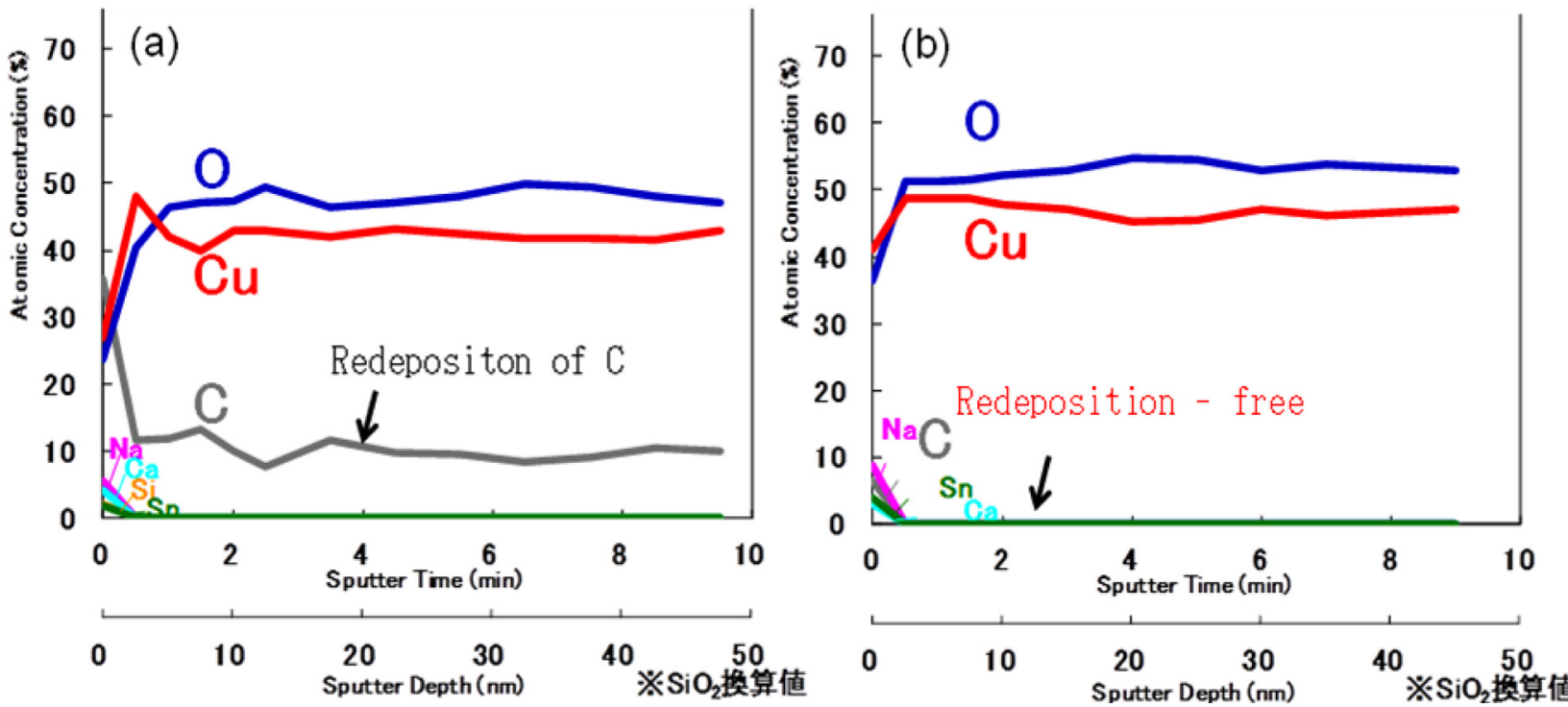

Fig. 5. AES depth profiles of copper oxide particle, (a) fixed by organic double-sided tape, and (b) fixed by Nitto Gecko ${ }^{\circledR}$ tape. The detected carbon of the sample fixed by Nitto Gecko ${ }^{\circledR}$ was much smaller than that fixed by organic double-sided tape, indicating that the carbon re-deposition from Nitto Gecko ${ }^{\circledR}$ was very little during the sputter depth profiling. 
チング物の再付着によると推定される炭素が検出さ れている.しかし, Nitto Gecko ${ }^{\circledR} て ゙$ 固定した試料の場 合, 試料表面の污染が少ないだけでなく, 試料内部 からも炭素は検出されず, 固定部材由来の成分を検 出しない試料表面および内部の評価が可能となる.

\section{3. 結論}

今回, カーボンナノチューブの材料特性に注目し, 従来の粘着剤ではなしえなかった, 非污染, 良導電 性, 低ドリフトの機能を活かせる分析試料の固定部 材としての産業応用を検討した。 その結果, 単に汎 用製品の代替や改良品でなく, 固定部材の影響が無 視出来ない微細形状や極表面の分析を行う分析で優 位性を持つことが示された. 固定部材を使わない紛 体の試料調整手法として錠剂成型する手法もあるが, 成型時の強い圧力で試料表面が物理的に破壊される 懸念がある. 一方, Nitto Gecko ${ }^{\circledR}$ を用いることで試料 表面の物理的破壊を抑える効果も期待できる。本稿 の検討結果は分析用途だけでなく, 真空, 高度な非 污染が要求されるような局所領域での固定を必要と する産業の技術発展に役立つものであり, 従来とは 異なる粘着テープ製品の市場開拓に役立つことが期 待される.

\section{4. 参考文献}

[1] Y. Maeno and Y. Nakayama, Appl. Phys. Lett. 94, 012103 (2009).

\section{査読コメント，質疑応答}

\section{查読者 1. 橋本 哲 (JFE テクノリサーチ)}

この技術報告用の原稿は. SEM 観察や表面分析 における試料保持用に使われているカーボンテープ などに比べて, 帯電抑制, 污染などの, 試料保持法 に起因する問題を軽減できる新しい材料に関するも のであり，その開発者による技術紹介です．本内容 は, JSA の読者にとって, 有意義であり, 本誌への 掲載は適当と考えます。しかし，本技術の理解を進 める上で，修正した方が良い部分があります。それ を以下に示しますので, ご検討をお願いいたします.

\section{[查読者 1-1]}

2.2 節の TOF-SIMS 分析結果に関して, “また, 粒子を錠剤成型し分析試料とした場合は試料表面が 物理的に破壊され，測定したい面を評価できない可 能性がある.一方, Nitto Gecko ${ }^{\circledR}$ を用いた固定をする ことで, 微粒子の表面を破壊することなく, ノイズ 成分を含まない評価が出来る。”との記述があります が，この説では，污染とイメージの向上についての み, 記述されています。“物理的破壊”に関して, 何 らかの実験的な根拠を示していただくか, あるいは 1 章の“はじめに”で，あるいは 3 章の結論で, プラ ス $\alpha$ の効果として記述いただくか，の方が適当と思 います。

\section{[著者]}

破壊はデーターが無いので TOF-SIMS の節からは 省いて， 3 章に期待される $+\alpha$ の効果として記入し ます。

\section{[查読者 1-2]}

“Au 表面の污染物質によりコントラストが不明 瞭になる”との記述があります。“污染物質”とは何 か? これがどうコントラストを不明瞭にしている かを記述してください. 寸なわち, Au が ABS 樹 脂に付着していると言うのか, $\mathrm{Au}$ に含まれる物質 が付着していると言うのかなどの観点でお願いしま す. 


\section{[著者]}

$\mathrm{Au}$ 表面の自然コンタミ由来のシグナルが無視で きないレベルにありマッピングで $\mathrm{ABS}$ 樹脂/ $\mathrm{Au}$ 界面 が不明瞭になっている事を記入します.

\section{[查読者 1-3]}

2.3 節の FE-AS 分析結果に関して, “, 固定部材 由来の炭素の再付着により試料内部からも炭素が検 出され, ”と記述されていますが、試料内部には炭素 はほとんど存在していないと思いますので，表現を 変えたほうが良いと思います。例えば“, 固定部材由 来の炭素の再付着により,十分スパッタした後でも、 炭素が検出され, ”など.

\section{[著者]}

炭素が試料内部から検出される理由を記入いたし ます。

\section{[査読者 1-4]}

結論で，“異なる使用環境”とは何を意味していま すか? 具体的に，かつ簡単に記述してください.

また，“技術発展”は大変広い概念です，どのよう な技術の発展に役に立つのかを，簡単に記述してく ださい.

\section{[著者]}

具体例をあげて追記いたします。

\section{[査読者 1-5]}

何箇所か “ノイズ成分を含まない”との表現があ ります。試料成分の強度に対する, 分析によるアー ティファクトによる重畳分をノイズと表現されてお り，感覚的にはわかります。しかし，表面分析にお いてノイズとは，狭義には，ある成分の信号強度に おける強度変動を意味しているので, 表現法を変え たほうが良いと思います。

うまく書けてはいないのですが “強度に対する試 料保持法に起因する重畳を低減でき”など，工夫し

\section{[著者]}

ノイズの定義へのご指摘ありがとうございます. 修正いたします。

查読者 2. 伊藤（コニカミノルタテクノロジー）

カーボンナノチューブ繊維構造体を試料固定に用 いることで，表面分析でありがちな絶縁性試料の測 定，観察における様々な課題を克服できることが示 されており，掲載の価值があると判断します.

\section{[査読者 2-1]}

参考文献は示されておりますが，簡単に固定の原 理を記すほうが分かりやすくなると思います。

\section{[著者]}

簡単に固定の原理を追記します.

\section{[査読者 2-2]}

2.2 章内で,

真空系の分析装置で試料を固定する際によく用い られる導電性テープ, 金 $(\mathrm{Au})$ そしてヤモリテープ で固定した粒子の表面を TOF-SIMS で分析し比較す ると, ・・・

とありますが，ヤモリテープという単語が突然出

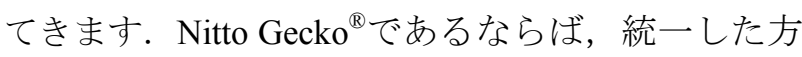
が分かりやすくなると思われます。

\section{[著者]}

Nitto Gecko で統一いたします. 